Article

\title{
From Traditional to Transnational: The Chung Family History as a Case Example
}

\author{
Haiming Liu \\ College of Education and Integrative Studies, California State Polytechnic University, Pomona, CA 91768, USA; \\ hliu1@cpp.edu
}

Received: 4 March 2019; Accepted: 5 August 2019; Published: 8 August 2019

check for updates

\begin{abstract}
A harmonious family of three generations living under one roof is often an assumed image of a Chinese traditional family. In reality, few Chinese families resemble this image. My article uses the Chung family history to illustrate how a family in rural Guangdong, South China, experienced a fast social ascent or descent in one generation. Its history reveals many aspects of Chinese family tradition, such as filial piety, equal inheritance system among sons, or education as an important family agenda. The rise and fall of this family also helps us understand the competitive social environment of Guangdong that sent hundreds of thousand immigrants overseas in the mid-nineteenth and early twentieth century. When some members of the Chung family migrated overseas, other members followed. The Chung lineage, similar to numerous Cantonese immigrant families in America, became transnational in culture.
\end{abstract}

Keywords: filial piety; equal inheritance system; ancestor halls; village schools; migration; and transnational; Chinese family culture

\section{Introduction}

A harmonious family of three generations living under one roof is often an assumed image of a Chinese family. Sons revere parents; wives obey husbands; and brothers help each other in family affairs. While women did household chores, men toiled in carefully cultivated tiny rice fields in self-sufficient farming. This image stands for inadaptability and the changeless nature of Chinese family culture. Nothing resembles this image in reality. As a Chinese saying goes, the wealth of a family lasts no more than three generations (Fu bu guo san dai 富不过三代). British historian Hugh Baker keenly noted that the rise and fall in family fortunes in the 19th century meant Chinese society was similar to a seething cauldron, with families bubbling to the top only to burst and sink back to the bottom. ${ }^{1}$ In this article, I use the Chung family as an example to show how a family in rural Guangdong, South China, could experience a fast social ascent or descent in one generation. Its history reveals some of the most important Chinese family traditions, such as filial piety, equal inheritance principle among sons, or education as an important family agenda.

The rise and fall of the Chung family are more than a tale of family feuds over property. It also shows how Chinese families negotiated and adapted to the competitive economic and social environment of Guangdong in the 19th century. Some succeeded; many failed. Guangdong sent hundreds of thousand immigrants overseas between the mid-nineteenth and early twentieth century. When Yitang (Yick Hong Chung) and his eldest son Sam (Weixi Chung) of the Chung lineage migrated to America in the 1900s, other lineage members followed, and their kinship network transplanted overseas. Most

$1 \quad$ (Baker 1979). 
of them settled in America, but their ties to home were never severed. Similar to many immigrant families from Guangdong, the Chung family became transnational in life and culture. As immigrants, Yitang and Sam worked hard to support the family. As parents, they made sure their children could get a good education. They encouraged them to pursue educational opportunities in both China and America and maintain both English and Chinese ability. In Chinese family culture, the children's education was always a priority. When Yitang and Sam retired, they did not accumulate much wealth for themselves, but all their children had accomplished college education.

The Chung's family originated from a narrow region along the Zhujing (Pearl) River Delta in Guangdong Province. The Chinese immigrants from this region further divided themselves based on three geographic districts- "Sanyi", "Siyi", and Zhongshan County. Sanyi included the districts (or counties) of Nanhai, Panyu, and Shunde; and Siyi included the counties of Xinhui, Taishan, Kaiping, and Enping. ${ }^{2}$ The Chung family lived in Niushan (Cattle Hill) Village, Kaiping County. The village had about four hundred families belonging to several different clans. Four families established ancestral halls and operated two to four schools, though not on regular basis. Among several rural markets in the area, the nearest one to Niushan Village was called Yung Ku Market, which operated all year round. The village had four wells for drinking water. In front of the village was a river that villagers used for irrigation in farming. There were also boats that transported villagers to and from Canton (Guangzhou) City. At the back of the village was a long brick wall with several gates. The Chung house was located in the heart of the village and was about one block away from the nearest gate. There were several family clans in the village. The Chung family was one of them. ${ }^{3}$

\section{The Origin of the Chung Family}

In China, some families composed and preserved books of genealogy, while many others passed stories of their ancestors orally from one generation to another. In a slight exaggeration, a British diplomat in the early twentieth-century China noted that "the commonest Chinaman can trace his descent back by memory from two hundred to five hundred years, or even more by referring to his 'genealogy' book at home". ${ }^{4}$ We could not find a formal genealogy book for the Chung family, but Sam Chung, a pioneer immigrant of the family, wrote numerous letters to his children, brothers, uncles, and other relatives after arriving in America. Letter writing was an important tradition in Chinese family culture. Sam seemed thoroughly familiar with his family history. Many of his letters recounted events, stories, or anecdotes about his ancestors and other family affairs. Based on the Chung family letters and other archive materials, I could trace the Chung family origin from Sam's father Yitang to his grandfather Chunli and great grandfather Zhandong, and compose a rough three- to four-generation genealogical history of the Chung family (Supplementary Materials) in Guangdong. ${ }^{5}$ As we put pieces of information together, the Chung family story is detailed enough to inform us of some of the most important aspects of family culture in rural Guangdong. It also shows how a Cantonese immigrant family became transnational in culture.

Sam's great grandfather Zhandong (1780-1830) was the eldest son of a well-to-do farmer's family and had five brothers. He married Nie, daughter of a well-to-do family in a neighboring rural town, Beizha, who bore him one son and two daughters. Sam believed that the Chung family began to gain

2 Sanyi (Sam Yup in Cantonese), translated as the "Three Districts", is located to the west of Guangzhou (Canton); Siyi (Sze Yup in Cantonese), translated as the "Four Districts", located to the southwest of Sanyi; and Zhongshan (Heungsan in Cantonese) County located to the south of Sanyi. "Yi" actually means county or district in Chinese.

3 (Liu 2005).

4 (Parker 1901).

5 Information on Zhandong and Chunli is based on a genealogy of the Chung family composed by Lillian Wong, Yitang's daughter, an Announcement of Yitang's 70th Birthday Celebration, Special Booklet of Sam Chang and His Wife's 80th Birthday Anniversary, n.d. composed by Tennyson Chung, and transcripts of Nellie Chung Interview and Arthur Chung Interview conducted by Chinese Historical Society of Southern California in 1985, and Sam's letter to Tennyson and Constance on 3 January 1928. I have copies of those documents. Also see Liu, The Transnational History, pp. 13-28. 
wealth and social status from Zhandong's generation. In a letter to his children, Sam Chung explained why Zhandong deserved great respect in the family history:

Zhandong inherited a farm from his aging father that produced no more than a hundred dan of grain (one dan equates to approximately one hundred and eighty-five pounds) He worked hard, lived a thrifty life, and was able to increase his grain yield up to one thousand dan a year. That is his first achievement. Second, he was an educated person, knew law, and could write and handle legal papers and documents for relatives and friends. Third, he knew how to deal with the local tyrants when they tried to take advantage of his wealth. He avoided a lot of trouble. Fourth, he viewed polygamy as the root of misfortune. When he became the wealthiest man in the village and had only one son and two daughters, he did not marry more wives for more sons. Fifth, though he could inherit the best house of the family as the eldest son, he gave it away to the widow of his half and fifth brother out of his respect for his father's wish and chose a smaller house for himself. Sixth, as the eldest son, he made sure that the six brothers remained close and friendly long after their parents passed away. Seventh, he maintained a decent life style. Relatives who were addicted to opium smoking and gambling always stayed away from him. Eighth, in addition to farming, he ran a reading class and taught children of the clan until he was old. As descendants, we should learn the above eight qualities from him. He lived only about fifty years but he was a very happy person and enjoyed life in his senior years. ${ }^{6}$

Though the letter was not a detailed biography, it was long enough to reveal what Sam perceived as some of the most important qualities of Zhandong as an ancestor in the Chung lineage. He was an educated farmer, a benevolent eldest brother, and a person who preferred a small family. It is important to note that Sam did not begin his description of Zhandong by portraying him as a great model of filial piety. Zhandong was obviously a nice person respecting his father and taking care of his widowed sister-in-law. In Sam's letter, however, his first and most important quality was the ability to expand his farming wealth ten-fold in less than thirty years.

According to the letter, Zhandong inherited a farm that produced about a hundred dan of paddy rice per year. ${ }^{7}$ Since the average annual yield of paddy rice per $m u$ (one $m u$ equals one-sixth acre) in Zhujiang Delta was between two to four dan during that period, we could assume that the size of his farm was between twenty to thirty $m u$ large. ${ }^{8}$ Though Zhandong's farm was modest in size, it was above self-subsistence level. In the early nineteenth century, one dan of grain could feed an adult male for a hundred days, or sell for three hundred copper cash. An agricultural laborer's monthly wage was only between two hundred and four hundred and fifty copper cash. ${ }^{9}$ Zhandong was in his late twenties when he inherited his share from his father's estate and retired from farming in his mid-fifties. In less than thirty years, he was able to expand his farming wealth ten-fold more than what he had inherited from his father. This was an impressive accomplishment in rural Guangdong. Sam's letter provided no details on how he accomplished this success except, praising his fugal lifestyle and hard-working spirit. Zhandong was obviously not a self-sufficient farmer who worked just to feed his family but a speculative agribusiness person who grew crops for sale. As anthropologist William Skinner observed, some speculative agribusiness people were able to expand their landed property and became rich within a short time because the commercial marketing system was well developed and organized in rural Guangdong. ${ }^{10}$

6 A letter from Sam to Tennyson and Constance on 3 January 1928.

7 One dan is equal to 2.94 US bushels and 1 hectoliter or equates approximately one hundred and eighty-five pounds. See (Faure 1989).

8 For the average yield of paddy rice per $m u$ in the Zhujiang Delta, see Faure, The Rural Economy, p. 48.

9 (Mazumda 1998).

10 (Skinner 1971). 
Between the late eighteenth to early nineteenth century, Guangdong was undergoing dramatic demographic changes. Its population grew from sixteen million in 1787 to twenty-eight million in $1850 .{ }^{11}$ According to historian Ping-ti Ho and Frederic Wakeman, Jr., the ratio of population to cultivable land in 1787 was 160 persons per square mile. It increased to 192 persons per square mile in 1812. The average cultivable land per person was $1.67 \mathrm{mu}$ in Guangdong, which was below the national average of $2.19 \mathrm{mu}$ in that year. ${ }^{12}$ This was a period of increasing social stratification and commercialization of farming. Cash crops began to replace self-sufficient farming in Guangdong. ${ }^{13}$ Life in a rural village was diverse and villagers' economic pursuits were multi-dimensional, since arable land could hardly meet the needs of the local population. As D. H. Kulp noted, a rural village in Guangdong could have clerks, salesmen, merchants, fruit dealers, carpenters, doctors, tailors, teachers, and many others, in addition to farming laborers and farmers. ${ }^{14}$ Many villagers did not own land. The average ratio of land to population in Guangdong was $7.8 \mathrm{mu}$ per family and only one million farmers owed their own land out of a total 12.5 million agriculturalists. ${ }^{15}$ Rice was not the only crop in Guangdong. The Zhujing Delta also produced silk and sugar-cane. In the hilly areas, people grew tea, tobacco, vegetables, and various fruits. While some farming families toiled in carefully cultivated tiny rice fields for survival, many others pursued other livelihoods. Though arable land was insufficient, the Delta was one of the richest agricultural areas in China. Diversified commercial activities, prevalent lineage organizations, and a competitive social environment characterized rural Guangdong.

Zhandong was well educated, although he was not scholarly enough to earn a degree title through the civil service examination. Sam listed education and legal knowledge as his second most important qualities. He was rich but not malicious, and a highly respected farmer in the village. "When his wealth sometimes made him the target of envious and rapacious people, Zhandong's ability to write legal complaints enabled him to defend himself and gain the upper hand in the conflicts with other people during arbitration by the local government" ${ }^{16}$ During the Qing Dynasty, the land ownership system, legal codes on land property, and land sale procedures were all complicated issues. For example, tenant farmers could have permanent access to land as long as they paid tax. As permanent tenancy became another form of ownership, many properties could have two or three owners. ${ }^{17}$ Zhandong could not accumulate his land property smoothly without knowing the law. His ability to write legal documents was an important skill. A common legal document in Guangdong was the contract for renting, leasing, or tenancy ownership of family farming properties. According to James Hayes, most of social and economic transactions in Qing China were done in writing, and writers of such contracts were not parties to the transaction but probably their follow villagers, clansmen, or fellow townspeople. ${ }^{18}$ Zhandong was literary enough to handle commercial farming issues for himself or his fellow villagers.

Zhandong also enjoyed teaching. While farming, he taught children in a village school in his spare time and became a full time teacher after he retired. Zhandong's legal knowledge was rare among farmers but his teaching career was normal in rural Guangdong. Many villages had schools. Large clans usually built ancestor halls (ci tang) and used them as schools. Children attended them if their parents paid tuition. Many villagers, especially males, had a functional literacy because schooling was an integral part of the rural life in Guangdong. Ping-ti Ho's research on social mobility in imperial China emphasized that literacy was essential for the farmer families, not only for pursuing scholarly

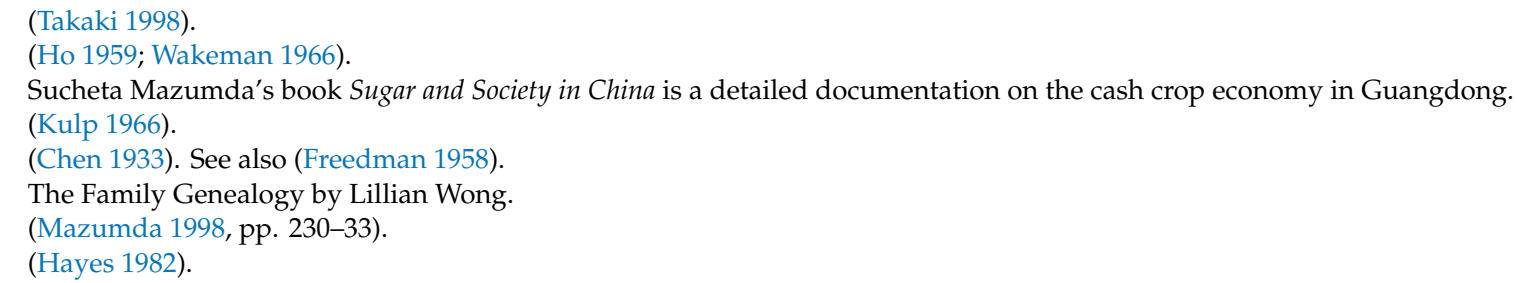


titles but also for successful farm management, and consequently there was a high degree of literacy among Chinese farmers. ${ }^{19}$

Sam spoke highly of Zhandong's kindness towards his brothers. In Chinese family culture, there are two words that denote filial piety— "xiao 孝" and " ti 悌". While "xiao" refers to respect and obedience to parents, "ti" means kindness toward siblings, especially brothers. In "ti" relationships, junior brothers should defer to their elder brothers, while the latter should display affection and care in return. In Chinese family culture, filial piety means respect to parents and affection for siblings. According to Sam, Zhandong was a caring and generous brother. As the eldest son, Zhandong could demand the best house of the family estate in property division, but let the widow of his fifth and half-brother take it. He set a good example of "ti" in sibling relationships. Sam saw him as a role model and carefully handled his own sibling relationship. When he joined his father Yitang in America, his father's second marriage added four younger siblings to the family-three half-sisters and one half-brother. Sam treated his American-born siblings kindly.

Sam admired Zhandong for his preference of a small family. Chinese family culture allowed polygamous marriage, as filial piety principle also encouraged men to marry concubines in order to have more sons to continue the family line. Zhandong had one son and two daughters but did not marry concubines to have more sons. He chose to have a small family with one wife and three children in order to maintain a harmonious family relationship. Chinese family culture disapproved of primogeniture and emphasized equal inheritance of family property among sons. However, more sons meant more competition over family property. A small family allowed Zhandong to keep his wealth undivided and give his only son Chunli a comfortable life and a good amount of wealth. He enjoyed a peaceful retirement life. Sam spoke highly of Zhandong's decision not to marry concubines because he knew how siblings of his father's generation mercilessly fought over property, which led to the decline of the Chung family.

\section{An Ancestor of Eighteen Children}

As the only son of Zhandong, Chunli (1805-1884) inherited all farming and housing property of the family. The Chung family's wealth continued to grow-from the wealthiest family in the village to one of the wealthiest families in the county. Several family documents mentioned that Chunli could collect four thousands dan of rice annually, which was four times larger than what Zhandong did. With this amount, Chunli probably owned or leased up to five hundred $m u$ or more of land, and had tenant farmers working for him. Chunli was known as one of the wealthiest landlords in Kaiping County of his time. Similar to Zhandong, he was an agribusiness person growing crops for sale rather than just to feed his family. He had tons of grain in the barn and a huge holding of land assets. ${ }^{20}$ He could use the profit from sales of grain to purchase more land and expand his farming property. There were several markets close to Sam's village and the largest one was about six $l i$ (one Chinese $l i$ is equal to 0.31 miles) to the south of it. ${ }^{21}$ Bustling with all kinds of farming or other products, markets in xiang were the focus of villagers' economic and social activities, and an integral part of the rural life in Guangdong. ${ }^{22}$ During the Qing period, markets in rural Guangdong became very specialized, with fruits, grain, silkworm, pig, draft animal, fish, or even fabric markets opened regularly at various locations. ${ }^{23}$ Commercial activities were common among rural populations in the Chung family area. According to William Skinner, the market towns were so important that they shaped the local social structure

\footnotetext{
(Ho 1962).

The above information is from recollections of several old friends contained in Special Booklet.

21 One Chinese $l i$ is about 0.3107 mile. For location information, see the Chung family immigration files in the Records of the INS-Los Angeles District Segregated Chinese Case Files, 1893-1935: Files 4935/6 (Box108) at NARALN.

22 For a detailed discussion of market towns in Guangdong, see (Marks 1984).

23 (Yang and Zhong 1996). Mei and Zhang, eds. Wuyi huaqiao huaren shi.
} 
and integrated the peasant community into the total society. ${ }^{24}$ Chunli's family lived a comfortable life based on the rents paid by tenants. This was a period when many farmers went bankrupt and became tenant farmers or farming laborers. In the mid-nineteenth century, three to five percent of the population controlled about fifty to sixty percent of the cultivated land. Moreover, interregional and international trade led to the cultivation of cash crops rather than subsistence farming. ${ }^{25}$ In rural Guangdong, there were people living in poverty, as well as people such as Chunli who speculated and accumulated wealth fast through commercial farming.

As family wealth increased, the size of the Chunli family began to grow accordingly. In contrast to Zhandong, Chunli married four women. The first wife, Chen, died shortly after marriage without bearing any children. The second wife, $\mathrm{Wu}$, bore him five sons and two daughters. Then Chunli married Liang as a concubine who bore him another five sons and one daughter. The eldest, second, fourth, sixth, and eighth sons belonged to $\mathrm{Wu}$, while the third, fifth, seventh, ninth, and tenth sons belonged to Liang. When $\mathrm{Wu}$ died, Chunli married Yuan and gave her status as a wife rather than a concubine. When Chunli married Yuan, he was almost sixty years old, while Yuan was only nineteen. Chunli granted Yuan a wife status for fear that she would not agree to this marriage as a concubine due to the age gap. Yuan bore him another two sons and three daughters, including Yitang (1866-1952), who was the eleventh son of Chunli. Through marriage to four women, Chunli had twelve sons and six daughters in total.

In Chinese family culture, the idea of filial piety includes proper marriage and having sons to continue the family line. As Mencius said, having no male heir was the worst of three offences against filial piety (bu xiao you san, wu hou wei da 不孝有三, 无后为大). It was not uncommon for Chunli to marry four wives and have eighteen children as a wealthy man in traditional Chinese society. Different from his father, Chunli wanted to establish a large family, as a large family could expand into a large lineage. Since the late seventeenth century, lineage organizations proliferated in Guangdong due to the social unrest. Bandits sometimes attacked the villagers during the harvest time. Armed feuds between Cantonese and Hakka over land disputes were common. There were also frequent physical fights over property between rival lineages or tenants' rebellions against rent collection. The lineage system was so prevalent that most rural inhabitants belonged to one or two lineages in that area. ${ }^{26}$ As endemic violence was part of rural life in Guangdong, a large family or a strong lineage organization was a reliable safeguard against bullying, looting, or bandit attacks.

\section{Education and Ancestral Hall as Symbol of Success}

As a wealthy man, Chunli sought to elevate his family's status by building an ancestor hall. Building ancestral halls reflected ancestor worshipping in Chinese culture. In rural Guangdong, however, ancestral halls were far more numerous than other provinces. As Qu Dajun observed in the 1690s, "Every clan, big or small, have ancestral halls built in grand style and which function as lecture rooms. A clan of one thousand people could have several dozen ancestral halls". ${ }^{27}$ Beginning in the seventeenth century, ancestral halls proliferated across the province. A shortage of arable land, commercial farming, and social instability all contributed to the growth of clan organizations. Building ancestral halls reflected the importance of the lineage organization in rural Guangdong. Chen Hansheng noted that one village of about seven hundred inhabitants in Guangdong maintained over forty ancestral halls, though they belonged to one huge clan. ${ }^{28}$ Wealthy and powerful families placed memorial tablets of their ancestors in it. The ancestor usually belonged to the lineage or the clan.

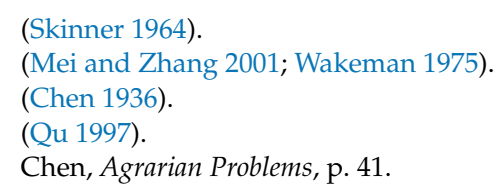


Tablets in the family shrine could be preserved for at least four generations. In Chunli's time, building ancestral halls displayed the wealth and social status of a family.

Similar to other wealthy families, Chunli invested in his children's education. The ancestor hall that Chunli built also functioned as a school named cuncheng shushi (Preserving Sincerity Study House). The village had four ancestral halls and all of them were used as schools. There were numerous village schools in Guangdong Province during the late Qing period. Cuncheng shushi was a school for the Chung lineage but open to other children in the village as well if they paid tuition. Having an ancestral hall and a school meant the Chung family became influential in the village affairs, with Chunli as the family head. After attending a village school such as the Chung family's cuncheng shushi, some gifted children of an ordinary family could go to more advanced schools called shuyuan (academic institute), located in towns and cities, and take a local civil service examination. The shuyuan system began in the Tang Dynasty as a private education institute and became popular in the Song Dynasty (960-1275). Guangdong had many shuyuan by the 19 th century. ${ }^{29}$ Education was an important channel for social mobility in China because of the civil service system. Chunli invited local scholars to teach at his school in the hope that his children could pass the local civil service examinations and become government officials. Village schools could not guarantee the success of every student. Most students probably dropped school to pursue other possibilities of livelihood, but many rural children were able to obtain functional literacy.

Through the civil service examinations, educated men could earn scholarly titles of three levels一xiu cai (秀才), ju ren (举人), and jin shi (进士). The highest title was jin shi, which almost guaranteed a position in the government. Ju ren ranked second and was eligible for government positions at the provincial level. Xiu cai was the third, and may or may not get a government position. ${ }^{30}$ As Confucius said, good education leads to officialdom. Among Chunli's children, his eldest, second, third, fourth, fifth, and sixth sons passed the preliminary county test (xiang kao 乡考). Biaobing, his eldest son, became a bingsheng (禀生), the paid xiu cai licentiate, while others became fushen (副生), the supplementary licentiates without pay. Bingsheng was the first place winner in a local preliminary county test and was eligible for a position in the local government, and received a government stipend before his appointment. As a bingsheng, Chunli's eldest son became an education official in Shunde County, a neighboring county to Kaiping. As historian Wakeman observed, "The Canton basin was one of the most academically prestigious areas of the country. During the Ch'ing period, Kuang-chou Fu ranked fifth among the nation's prefectures in the number of chin-shih (Kuang-chou Fu is Canton and chin-shih is jinshi)".31

Family life reflected Chinese social structure. With scholarly titles, sons of Chunli brought honor and prestige to the Chung family. Even without being a government official, they made the Chung family part of the gentry class in Chinese society. A family of gentry class was exempted from local taxes, public manual labor, and corporal punishment in court. The local government respected the gentry families and treated them as community leaders. ${ }^{32}$ Through schooling at shushi and shuyuan, people from ordinary families could change their class status. Education in traditional China led to prestige, power, and wealth. Susan Mann defines the family system, civil service examination system, and patterns of male sojourning as three grand social structures that impacted human actions in traditional Chinese society. ${ }^{33}$ Early Chinese immigrants were mostly Cantonese and their community leaders were often holders of scholarly titles. Of the fourteen presidents from 1881 to 1927, the Sanyi Association, the largest Cantonese immigrant organization, had three jinshi, nine juren, and one gongsheng. By 1906, the Six Companies, an umbrella organization for all Chinese immigrants in America, had had four

\footnotetext{
(Grimm 1977; Hsiao 1960; Liu 1958).

For in-depth discussions on the civil service examination, see (Ho 2000).

Wakeman, Social Disorder, p. 181; Liu Boji, Guangdong shuyuan zhiduo, pp. 46-78.

(Zhang 1955)

(Mann 2000).
} 
juren as president. ${ }^{34}$ Some of those degree holders were probably merchants as well, and could have purchased their degree titles. In the late 19th century, wealthy families in China began to purchase scholarly titles when the declining Qing government permitted such purchases. The civil service examination system officially stopped in 1905.

\section{Sibling Feuds over Family Property}

Though family wealth reached its zenith during Chunli's generation, it began to decline when he was getting old and needed to divide family property among his sons. Chinese family culture disapproved of primogeniture. Every son was entitled to a share of the family property following the principle of equal inheritance among sons. According to Qing codes, even a son born of a proscribed sexual relationship, such as with a domestic maid, would receive half the share of a legitimate son. The father could not disinherit a son without a valid reason. ${ }^{35}$ One of the most common legal contracts in the late Qing Dynasty was the contract for family property division. In splitting family wealth, the rule of equal inheritance ensured that brothers were equal. All sons, whether they were the offspring of the primary legal wife or concubines, had rights in the patrimonial estate and property, as long as their father recognized them as sons. Chunli had twelve sons. As a competing sibling for family property, Yitang was much younger than most of his elder brothers. To make sure he could get his share of family property, his mother Yuan arranged for him to marry young. As Japanese historian Tadashi Fukutaku put it, "property division may take place either before or after the death of the father but generally occurs at the time of the marriages of the second and third sons, as harmonious family life is difficult to maintain when married brothers live together". ${ }^{36}$ In the Chung family's case, Chunli wanted to make sure that Yitang and his youngest son could receive an equal share of his property.

In 1882, Yitang married a girl named Guan from Langxia xiang, Kaiping County, when he was only sixteen years old. Guan bore Yitang three sons: Sam (Weixi), Zhongping (Weizong), and Elbert (Weiying). ${ }^{37}$ Yitang married young because he could not wait any longer, as Chunli was already seventy-seven years old. Some of Chunli's sons began to challenge his patriarchal authority. On one occasion, Chunli had a birthday dinner and his second son prepared his favorite food-a sea cucumber dish. When Chunli gave a piece of cucumber to Yitang, the second brother shouted at him: "This delicacy is a special food for you. Not for anyone else. You cannot give it away!" On another occasion, Yitang had a fight with a son of the second brother in school and slightly injured the head of his nephew with a wooden slipper. In revenge, the second brother chased him everywhere and wanted to beat him to death until Chunli interfered. ${ }^{38}$ Chinese family politics were delicate yet intensive. On the surface, the second son was competing for Chunli's affection and favoritism. In reality, he challenged Chunli's patriarchal authority, tried to enforce a hierarchical sibling relationship, and showed his power in family affairs. The first and second sons were rude to Chunli whenever they found him showing affection to the sons of his youngest wife.

After marriage, Yitang could have a house with its own kitchen (or stove), which marked independence. More importantly, Yitang could officially demand his share of family property and be treated as an adult member of the extended family. Chunli intended to divide his property evenly among his sons. According to a local practice, he could also have a share to the ratio of six-tenths to the son or sons of the primary wife, and four-tenths to the sons of concubines. Chunli's eldest and second eldest sons opposed this decision and wanted to maintain the land property in the name of the Chung lineage ownership. They were both degree holders and the most powerful brothers in the

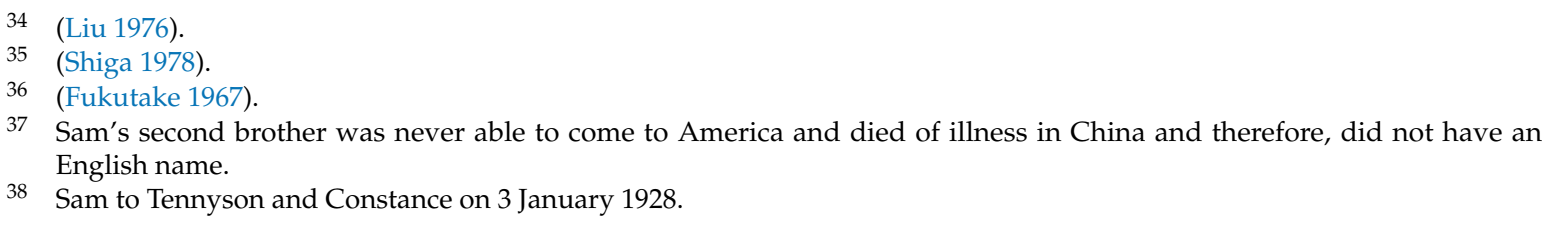


family. In Guangdong, some families or clans owned and managed land property this way due to the scarcity of arable land. The two eldest brothers wanted to control the entire farming property of the family in this type of ownership. Chunli insisted that one portion of his farming property be divided to each son and his family as a base to supply staple food. He passed away two years after Yitang's marriage and failed to solve his property division issue before his death.

After Chunli's death, the family conflict intensified. The second eldest brother sometimes physically attacked Yitang and his mother when feuds arose. On one occasion, there was no food left in Yitang's house as the two eldest brothers ordered the tenant farmers not to give any grain to them. As the family was starving, Yuan went to the farmland allocated to them by Chunli and cut the crop herself. When the second eldest brother heard this, he led a dozen of his family members and relatives to rush to the field and beat Yuan with bamboo sticks. Sam described the incident in a letter, "After they beat Yuan with bamboo sticks, there was blood all over her. Then they shouted that it was useless to kill this woman. Let us get rid of her son. The second eldest brother chased Yitang with knives in both hands. Yitang ran as fast as he could. He fled to a small hill, tried to jump over a pond on his way and then rolled down the hill, and lost consciousness. Someone later discovered and saved him". ${ }^{39}$

The physical attack on Yitang showed how brutal a family feud could be in Chinese society. Professor Ping-ti Ho pointed out that the custom of equal inheritance in Chinese society frequently gave rise to property disputes among brothers. Widows with minor sons often found it impossible to ward off the encroachment of rapacious brothers-in-law or other kinsmen. Ho cited an example in which a boy was thrown into the river by his uncle and was only later saved by a neighbor. ${ }^{40}$ Though Yitang narrowly escaped being lynched, the battle for family property became increasingly intense. Yitang and the other eight brothers formed a united front and called themselves the Nine Families, while the second eldest brother banded with the eldest and seventh brothers as the Three Families. The Chung brothers did not necessarily bind each other according to their maternal ancestors. The Nine Families shared a similar vision on how to divide family property. Their ultimate goal was to divide the family property evenly and get their share for their nuclear family. In general, it was the nuclear family rather than the extended family that was the preferred unit of consumption, production, and property ownership in Chinese society. Equal inheritance of family property among male heirs reflected that tradition. The Three Families wanted to control the entire family property themselves because the shortage of arable land in Guangdong allowed ownership of land under an extended family or a clan.

Male siblings' competition over family property demonstrated an inner contradiction in the Chinese family system. On the one hand, brothers had an equal claim to the assets of their family. According to the Qing law, all male descendants had the right to inherit a share of family property in land, houses, movable property such as furniture, clothing, livestock, and so on. On the other hand, male siblings were not equal in their family status. In the Chung family, for example, the eldest brother and second brother had more say in family affairs because they passed the civil service examinations and held scholarly titles. In Chinese family culture, as mentioned before, filial piety included the "ti" principle. Younger brothers were supposed to display obedience to older brothers, sometimes to the same degree as they did to their father. As an old saying goes, the eldest brother is similar to a father (zhang xiong ru fu 长兄如父). The Qing law coded that killing an older sibling deserved beheading. When older siblings killed younger siblings, the penalty was penal servitude or banishment. ${ }^{41}$ Such law could encourage elder brothers to abuse the "ti" principle and use physical assault in family feuds. Equal inheritance theoretically gave every male heir an equal share of family property, but in certain cases elder brothers could use the " $\mathrm{ti}$ " principle to their advantage. This contradiction in Chinese family culture made male sibling relationship a complicated issue in family politics. Dispute over the

39 Sam's letter to Tennyson and Constance on 3 January 1928.

40 Ho, The Ladder of Success in Imperial China, pp. 164, 302.

41 (Anonymity 1964). 
division of property, clashes over the support and treatment of parents, and abusive behavior by elder brothers could fragment a well-to-do family when an aging father lost his patriarchal authority in family affairs.

After Chunli's death, the Chung family declined rapidly. In a letter to his cousins, Sam wrote:

"Our marriage tradition is very different from the Western people. In the West, even if you have a millionaire father, you will not marry until you acquire a career to support yourself. The parents do not give money to children to encourage early marriage. After marriage, children and parents live in separate houses so that family conflicts are few. In our country, parents encourage their children to marry early. They do not care if they have enough food to feed the family but are only interested in having grandsons to show off. Life in a Chinese extended family is similar to hell. The rich, big families only produce parasites for the human world. Our ancestor Chunli's family is a case in point. Each son received two hundred dan of grain per year for his nuclear family. When the grain was processed into food, there was about one hundred and twenty dan left and forty dan of grain had to feed domestic animals. So each family only had eighty dan left. If one dan was worth two dollars, each family had about one hundred and sixty dollars a year. The children's education cost about thirty dollars; clothing thirty dollars; social activities twenty dollars; and medicine twenty dollars. They had very little money left. Yet many of our extended family members lived a befuddled life, only interested in getting concubines, opium-smoking, and gambling". ${ }^{42}$

Due to the family feuds, several siblings escaped to Canton (Guangzhou) with their spouses and children. Two of Yitang's sisters died of hunger, as daughters could not inherit family property. In his letters, Sam mentioned that some children and grandchildren of Chunli lived a parasitic life, gambling, smoking opium, and interested in having concubines. ${ }^{43}$ Sam concluded that Chunli was not happy in his senior years, although he earned four-thousand dan of grain annually, had eighteen children, and lived until seventy-nine years old. ${ }^{44}$

\section{Migration to America}

Yitang Chung and Sam also left their village to live in Canton. Both of them knew herbal medicine and further studied it to become practitioners. Yitang opened a medical office in the city, while Sam attended modern schools to adapt himself to the changing Chinese society. In a letter, Sam wrote: "I studied business for one year in Hong Kong, where they only taught me some mathematics and English. Then I studied at the Guangdong Police Academy for two years. I also studied Chinese traditional medicine. After working for the government, I have been very busy and have had little time to read books". ${ }^{45}$ Sam became a learned man. While widely read in Chinese classics, such as Confucian teaching or Tang poetry, in addition to writing classic poems himself, he also had strong interests in the writings and ideas of radical and reformist intellectuals of his time, such as Sun Yatsen, Kang Youwei, Liang Qichao or Hu Shi, Chen Duxiu, Cai Yuanpei, and translations of Western political and literary writings.

In 1900, Yitang migrated to the United States as an herbal doctor. During the Chinese exclusion period (1882-1943), an herbal doctor was a merchant in class status and eligible for admission. He established an herbal medical business in Los Angeles and remitted money to support his wife and three children in China. In the daytime, he mainly served the non-Chinese patients in his residence and office on Ninth Street. In the evening, he rented an office room above Tsui Fai Low Restaurant

\footnotetext{
42 Sam to Tennyson on 4 December 1928.

43 Sam to Tennyson on 4 December 1928.

44 Sam's letter to Tennyson and Constance on 3 January 1928.

45 Sam to Tennyson on 25 December 1921.
} 
in Chinatown. ${ }^{46}$ The Chinese population in Los Angeles was concentrated in two areas; Chinatown, next to the Plaza, and an area to the east of Adams Boulevard district. By 1910, while being a residential area for the Chinese, Chinatown had at least fifteen restaurants, many gift shops, grocery stores, herbalist offices, and Chinese organizations. The Chinese community in the East Adams Boulevard area gradually expanded to Ninth Street. Many Chinese farmers or farming laborers in the produce business lived there. ${ }^{47}$ After his wife passed away in China in 1908, Yitang married Nellie Yee (Yu), an American-born woman, on 2 June 1910. He was already forty-four years old, while Nellie was twenty-two. During this period, women only made up a small percentage of the Los Angeles Chinese community. The U.S. Census recorded 2455 men but only 147 women. ${ }^{48}$ Yitang was fortunate to be able to form a new family. Chinese Exclusion Laws made it very difficult for Chinese immigrants, even merchant class immigrants, to bring their wives and children to America. With a new family, Yitang's life in the United States became stable. Nellie bore him four children: Lillian (Qiaoxin or Kow San) on 31 March 1911, Arthur (Weixun or Wei Soon in Cantonese) on 31 December 1913, Marion (Qiaoshang or Kow Shung) on 8 October 1920. and Marie (Qiaozhuang or Kow Shung) on April 6, 1927. When the last two daughters were born, the family moved to 1322 South Hill Street. ${ }^{49}$

With income from the herbal business, Yitang invested in an asparagus farm of twenty-five acres in North Hollywood around 1915 in partnership with some relatives. When Sam arrived in the United States on a government mission that year, Yitang requested for him to stay and assist him in the family herbal and farming business. Sam practiced herbal medicine for a couple of years and then took over the management of his father's farm located at 4660 Whitsett Avenue in North Hollywood around 1918. Asparagus farming was a long-term investment and required sophisticated farming skill. Usually an asparagus farm could not produce a yield until the third year or longer. Harvesting first grade asparagus, a good laborer could cut only one acre per day. Under Sam's careful management, the farm began to yield asparagus in the third year. He became a master asparagus grower and could handle asparagus growing on both the rich soil and the sandy land. In addition to asparagus, he planted as many as a dozen other agricultural crops, including potatoes, sweet corn, hay, alfalfa, sweet potatoes, squash, pumpkin, watermelon, cabbage, and cauliflower. The family invested in a second farm in 1928 . With their herbal store and farming business, Yitang and Sam managed to sponsor more than forty cousins, nephews, and other relatives to the United States in the following decades. ${ }^{50}$ The transnational voyage of Yitang and Sam was not an individual adventure but a family-oriented relocation, with kinship relationship as a priority consideration.

\section{Names in Chinese Family Culture}

When Sam decided to stay in America, he had to re-establish his immigration status from a government visa to a merchant visa. He prepared numerous paperwork, went through several rounds of interrogation at the Immigration and Naturalization Service, and answered many questions. Many of the questions were about his family history. On November 6, 1923, Inspector J. C. Nardini and You Chung Hong, a then INS interpreter and later a well-known Chinese American immigration lawyer, interviewed him. Mr. Nardini began by asking Sam to list all of his Chinese names. Sam gave three: "Chang Wei, boyhood name; Chang Sue Yick, married name; and Chang Sheong Peoy, chosen name; no other names". ${ }^{51}$ In Chinese family culture, men could have several names-a given name in his nuclear family, a generational name used in the clan, or a nickname used by his parents and neighbors.

46 Nellie Chung Interview.

47 (Mason 1967; Cheng and Cheng 1984).

48 Cheng and Cheng, Chinese Women of Los Angeles, pp. 2-7.

49 Records of the INS-Los Angeles District Segregated Chinese Case Files, 1893-1935: 29160/141 \&142 (Box 358) at NARALN.

50 See Introduction Chapter of The Transnational History of a Chinese Family for the basic facts about the Chung family. They used both "Chang" and "Chung" in English spelling as their last name.

51 The Chung immigration files at the Records of the INS-Los Angeles District Segregated Chinese Case Files, 1893-1935: Files 5530/546 (Box 249) at NARALN. 
Sam's given name was "Chang Wee Chee" (Zhang Weixi in contemporary Romanization), which had already been used by two relatives in the early 1910s. One used Sam Chang's name and another used Yitang's second son Weizong's name (Chang Weizong or Cheung Tseng Gip; ${ }^{52}$ Weizong never came to America and passed away in 1927). Sam could not use this name any more and could not stay in America as Yitang's son. In his immigration files, Sam was not a son but a business partner of Yitang. This was why he used "Chang Wei" instead of "Chung Wee Chee" as his given name in the interview. He also spelled "Chung" into "Chang". Sam eventually obtained his merchant status, was able to stay, and sponsored his family members. In the last round of interviews regarding Sam's merchant status, Nardini pointed to a photo of Sam and asked Yitang: "Who is that person?" Yitang replied briefly: "Chang Wei, my partner". The answer ended the interview and covered the father-and-son relationship in their immigration papers. Ever since then they were never be able to address each other as father and son in public. The coverage was a painful episode in the Chung family history. Both Yitang and Sam understood that passing Sam as "Chang Wei" in the testimony was crucial to the collective interest of the Chung family in America.

Naming was an important component in Chinese family culture. Multiple names reflected a Chinese man's generational status in his nuclear and extended family. Every one of Sam's names was meaningful in its own way. Yitang had four sons-three by his first wife and one by his second wife. As the eldest son, Sam's given name was "Weixi" and his three younger brothers were accordingly "Weizong", "Weiying", and "Weixun". In Chinese lineage culture, the word "Wei" represented Sam's generation in Yitang's nuclear family. In the interview, Sam gave "Chang Sue Yick" as his "married name". There was no such a thing as a "married name" in Chinese family culture. He put "Chang Sheong Peoy" (Zhang Xiangpei) as a "chosen name" in the interview, and there was no such a thing as "chosen name" in Chinese family culture. Sam or other immigrants probably created name categories that sounded familiar to INS officers rather than listing their names according to Chinese family culture. In the Chung extended family, Sam's clan name was "Xiangpei", with the last character "pei" indicating the rank of his generation. In the extended family, Sam shared the "pei" word with all his male cousins. In the Chung lineage history, Yitang's clan name is "Pengbing", with "bing" being shared by all male members of Yitang's generation. "Yitang" was a courtesy name used socially in the circles of his friends, acquaintances, or his profession. He could choose any words for his courtesy name. Sam's courtesy name was "Chang Sue Yick" (Siyi). He listed it as his "married name" in the immigration interviews. Sam used "Xiangpei" when he wrote letters to his fraternal cousins and uncles, "Weixi" when he wrote to his brothers, and "Siyi" when he wrote letters to friends and acquaintances, and as his penname when he wrote poems and recollections of his life. Yitang and Sam sponsored several dozen of their relatives to the United States. Sponsored relatives were supposed to work in the Chang family's herbal or farming business. One letter from Sam indicated several relatives had invested in the farm. One relative named Tianpei was eager to cash out his profits and return to China. ${ }^{53}$ As mentioned before, Sam shared the "pei" word with all his male cousins. "Tianpei" was obviously one of them.

Sam was married in 1904. His wife, Zhiyuan Cen, was born in 1885 to a wealthy family in Enping County. Coming from a rich family, Cen knew how to read and write and was able to write letters to her children when they were away from home. Sam and Cen's first child was born in China in 1910, named Tingxun, who came to America in 1929 and adopted "Tennyson" as his English name. Their second child was Yuhua, a daughter born in 1912, who was named Constance after she came to America in 1923 with her mother. Similar to many Chinese parents, Sam gave his children Chinese names. Sam's son Tennyson was Tingxun in his Chinese name, with "ting" as the word to indicate his generation rank in the Chung family. He shared this character with all his male cousins. Sam gave his daughter

52 Records of the INS-Los Angeles District Segregated Chinese Case Files, 1893-1935: 4935/6 (Box 108) at NARALN.

53 Ibid. 
the word "Yu" as a generation word in their Chinese names too. As mentioned before, Constance' Chinese name was "Yuhua". Sam's third daughter Estelle was "Yuchu" and his fourth daughter Joyce was "Yuchzai". "Yu" means jade in Chinese and is Yook in Cantonese Romanization. Yitang's American-born daughters had Chinese names too. When Lillian Wong, daughter of Yitang, composed a family tree of the Chung family, she lists both their English and Chinese names. ${ }^{54}$ A traditional genealogy book of a Chinese family would not list the given name of a female member, whether she was a wife or daughter.

\section{The Chung Family Become Transnational}

If equal inheritance tradition made the Chung lineage a divided house, Yitang's migration to America helped the lineage members to re-organize themselves around him. His sponsorship included sons or grandsons of those siblings who had bullied him in the past. He also helped several relatives who had been driven away from the home village by the family feuds. Yitang's migration and sponsorship of relatives to America made him a highly respectable person in his lineage and home village. Around 1916-1917, several members of the Chung lineage proposed to build an ancestry hall in Yitang's honor. The lineage collected money, purchased a piece of land, planted trees around it, and named it Huai Yuan (the Beholder Garden). Sam wrote a biographical sketch of Yitang engraved on the tablet in the hall that read:

Having heard that America was the wealthiest country in the world, father decided to go there alone. He did business there for three years and then came back to see his aging mother as a filial son. He also sent his children to modern schools and believed that only reforms could make China strong. Following his idea, Weixi attended the Advanced Police Academy of Guangdong, Weizong went to the Guangdong College of Law and Administration, Weiying to the medical school at Georgetown University, and Weixun and Qiaoxin graduated from Los Angeles High School in America. When father was thirty-eight, he returned to America. Up until now, he has been in America for sixteen years and has managed to bring twenty to thirty relatives to America. ${ }^{55}$

Sam listed migration, children's education, and sponsorship of relatives to America as three Yitang's great achievements. Family history reflected changes and continuities in Chinese society. In 1905, the Qing government ended the civil service examination system. In 1911, China became a Republic. As an immigrant, Yitang wanted his children to pursue opportunities in both China and America. Yitang's third son Weiying (Elbert) came to the United States when he was twelve years old. After graduating from Georgetown University Medical School, he could not find a job in America but received an offer as an intern physician in the prestigious Beijing (Peking) Union Medical College established by the Rockefeller Foundation in China. Weixun (Arthur) was born in America but went to Nankai University in Tianjin and Yanjing (Yenching) University in Beijing for his college education, and then National Medical College of Shanghai for his medical degree. He worked as an established physician in China until he returned to America in 1975. Yitang's American-born daughter Lillian (Qiaoixin) went to work in China after she graduated from the University of Southern California in 1933.

In 1928, Yitang returned to China for a visit. The Chung lineage treated him like a hero. Yitang "swept" the tomb of his father, donated money to build a new road for the village, and also made his ancestor hall a school for the Chung lineage children and children of the poor in the village. To have an ancestral hall built in his name was a great honor for Yitang. Only men of outstanding achievement or contribution to the lineage or clan deserved such an honor. Building an ancestral hall

54 See Liu, The Transnational History of a Chinese Family, p. 211.

55 The original draft of this biography is still preserved in the collection of Sam Chang family papers. 
for an outstanding member of the lineage was a core value in Chinese family culture and especially prevalent in Guangdong. Yitang's sponsorship of relatives from China to America earned him great respect from his lineage. Rather than breaking away from home, Yitang's migration strengthened his ties with his lineage and enabled the kinship network of the Chung family to transplant from China to the United States. Yitang was not an exception in earning respect from his relatives at home as a successful immigrant. When hundreds of thousand Cantonese migrated overseas, many of them remitted money home and sponsored relatives to join them in America. From the late 19th century and the early 20th century, many ancestral halls with tablets in honor of those immigrants appeared in rural Guangdong. As Frederic Wakemen points out, "These tablets actually conferred genuine social status to those enshrined there, and to their descendants who came to pay ritual respect". 56

Together with his father, Sam remitted money to the Chung family and lineage, contributed suggestions and opinions regarding the management of the lineage property, and co-sponsored relatives to come to America. Sam farmed for over fifty years on the family farms in Southern California. Though he sometimes wanted to explore other careers and often talked about returning to China, a strong sense of obligation to the Chung family made him a life-long asparagus farmer in America. The two farms under his management became a reliable resource of family income and provided job opportunities for immigrant relatives and friends. While busy with his asparagus farming, Sam kept a close eye on his children's education. Similar to his ancestors, Sam valued education and viewed his children's education as an important family agenda. In order to adapt to the changing China and the racial environment in America, he arranged his children to attend to schools in both China and America. He believed that English ability was a marketable skill for his children, though they could have a better career in China as educated Chinese.

Sam carefully planned his children's education. When getting his family members to America, Sam first sent for his wife Cen and daughter Constance but asked his son Tennyson to complete his high school education in China before coming to America. In a letter in 1922, Sam explained to Tennyson that he decided to send for Cen and Constance first because U.S. immigration laws had become tougher and tougher for Chinese. Some politicians even proposed a total ban of Asian immigrants. ${ }^{57}$ However, Sam advised his son: "If you want to be a person of high social status, America is not the right place for you. But if you want to make money to help your family out of temporary difficulties, no other country's money is worth more than the American dollar". ${ }^{58}$ He asked Tennyson to complete high school in China, improve his English language ability, get into a top-tier Chinese university, and then transfer into a top-tier American university. In a letter, he told his son: "You are now sixteen and should study hard to have a good command of Chinese before you come here to study English, which is not so difficult. No great scholar can write a good English article if his written Chinese is poor. ${ }^{59}$ He wanted his son to think of his future in China. Sam urged his son to study in a school where English training was competent and the first choice should be Qinghua College in Beijing, which sent hundreds of Chinese students to study abroad every year. When planning his children's education, Sam seemed to possess meticulous information about education in China. He wrote: "If you cannot apply to Qinghua in Beijing this July, try it next year. Now you have been at Tongzhi School for three years. You will graduate in one more year. You can apply to Qinghua after graduation. If you cannot get into Qinghua, apply to Lingnan. After graduation from Lingnan, try to get into Beijing University. Then you can apply to an American university. But this plan costs a lot of money and takes too much time". ${ }^{60}$ Then he wrote again: "Lingnan is a good English language training institution. You should be

\footnotetext{
Wakemen, Social Disorder in South China, p. 113.

Sam to Tennyson on 24 May 1922.

Ibid.

Sam to Tennyson. The letter has no date but seems to be written around 1925 .

Sam to Tennyson on 25 December 1921.
} 
able to pick up enough English there before you apply to Qinghua or Beijing University. Then you could apply to come to America". ${ }^{61}$

As an immigrant parent, Sam knew that admission into a top tier university, such as Qinghua in Beijing or Nankai in Tianjin, would enable Tennyson to get a student visa when he was applying to an American university. Entering into the United States on a student visa was a lot easier than as an immigrant. Chinese exclusion laws did not ban the entry of students and U.S. immigration officers were more lenient when questioning student applicants. Sam told his son,

"You could apply for a visa directly from the American Counsel and be spared from complicated paper work and rough interrogation. You should apply to Qinghua College or study in Lingnan University. If you cannot get into Qinghua, you should try to get into Nankai University in Tianjin. Then you can come to America for a graduate school or as a transfer college student, which is the best plan for your education" ${ }^{62}$

Rather than an immigration scheme, Sam actually mapped out an ideal educational route for his son. An important goal in this route was to enter a good American university. Though Qinghua or Nankai in China could provide Tennyson an excellent modern education, a diploma from an American university was a necessary stepping stone to pursue a good career in China. As Rose Hum Lee notes, a more calculated plan for a Chinese family for its children's education in the early twentieth century included studying at missionary schools at an early age and later at institutions of higher learning that emphasized Western curricula. A good command of English from these schools paved the way for study abroad. The degree obtained in a foreign institution became the criterion for upward mobility and an established place in the Chinese social hierarchy. ${ }^{63}$

When advising Tennyson to leave Guangdong for North China, Sam provided specific instructions on how to travel from Guangdong to Beijing and Tianjin. In a letter of 1924, he wrote,

You should reserve your ship ticket through Hongfa or Tai-an Hotel. Around the departure, the hotel will contact you, tell you where to board the ship, and take you there. It will take three days from Canton to Shanghai. You can stay for one or two days in Shanghai at the Hongfa Hotel where Cantonese speakers are always available at your service. There are many swindlers in Shanghai. Most of the rickshaw men are thieves. You must be very careful. It will take four days from Shanghai to Tianjin by ship. Taida Company offers a reasonable ship ticket. It will probably cost twelve dollars to get to Tianjin. A member of the Chung lineage is a doctor in Tianjin but we do not have his address. You can stay in Tianjin for one day and take the train to Beijing the following day. You will arrive in Beijing at three o'clock in the afternoon. At the train station, there are many hotel agents. Choose Fuzhao Hotel and ask them to get you a rickshaw. The hotel is owned by Mr. Zhu of Qingyuan County of Guangdong and is located on Mule and Horse Market Avenues in Beijing. It will cost you sixty to seventy cents a day. After one or two weeks, you will be familiar with Beijing. Streets in Beijing, Tianjin, and Shanghai are much wider than streets in Canton and easier to locate. In Shanghai, British money is popular, while in Beijing and Tianjin, French and Japanese money are popular. ${ }^{64}$

After attending Nankai High School in Tianjin, Tingxun (Tennyson) came to America and earned a Bachelor's degree from the University of Southern California, a Master's degree from Columbia University, and a Ph.D. degree from Georgetown University. His first job was as a diplomat at the

61 Sam to Tennyson on 22 July 1922.

62 Sam to Tennyson on 27 April 1923.

63 Lee, The Chinese in the United States, p. 99.

64 Sam to Tennyson on 12 May 1924. 
Chinese embassy in Nicaragua. Sam's daughter Constance (Yuhua) was born in China and came to America in 1923. However, she returned to China four years later for her high school and college education. She did not come back to America until 1937. Sam's third daughter Estelle went to China when she was only eight years old and stayed there five years. By 1924, Sam had been away from China for nine years but his letter revealed an explicit knowledge about Shanghai, Beijing, and Tianjin. The most significant part of the letter is his description of Cantonese networks that could assist Tennyson to travel all the way from Canton through Shanghai to Tianjin and Beijing. Sam even knew the name of a Cantonese hotel owner in Beijing and his home district. Such knowledge informs us of how social networks of the Cantonese extended to metropolitan cities in East and North China and was available for traveling Cantonese if they needed local contract. Cantonese immigrants in North America had similar social networks.

This was a period when many Chinese American youth could not find jobs that matched their college education in America. ${ }^{65}$ Yitang and Sam did not hesitate to send their American-born or raised children back to China when racism blocked their children's career mobility in America. They worked hard in their herbal and asparagus businesses in order to provide a financial base for the younger generation to receive good education across the Pacific. In Chinese family culture, education was more than an individual ambition or personal interest but an important family agenda. Self-sacrifice of the parents, in return, obliged the younger generation to compete vigorously at school in order to pursue good careers for social mobility. Their educational success was not only an individual merit but represented the shared interest of a Chinese family. Instead of family collectivism giving way to individualism, we see compromise between personal goals and the greater good of the family as a collective. Sam's immigrant background, knowledge about China, and transnational world outlook assisted his children in exploring education and career opportunities in both China and America. Sam lived a long life and passed away in 1988 in Los Angeles at the age of 102 years old. One regret he had was that he never had a chance to return and visit his home country after his arrival in America in 1915. However, all of his children accomplished college education and became middle-class professionals. Transnational life and culture reflected not only the emotional attachment of Chinese immigrants to China. but also their aspiration for a better life and efforts to give more opportunities to their children.

Supplementary Materials: The following are available online at http://www.mdpi.com/2313-5778/3/3/46/s1.

Funding: This research received no external funding.

Conflicts of Interest: The author declares no conflicts of interest.

\section{References}

Anonymity. 1964. Daqing Luli Huitong Xinzuan [The Law of the Qing Dynasty. Taibei: Qing Court, vol. 4, p. 2795. Baker, Hugh D. R. 1979. Chinese and Kinship. London: The MaCmillan Press, p. 133.

Chen, Han-sheng. 1933. The Present Agrarian Problem in China. Shanghai: China Institute of Pacific Relations, p. 7. Chen, Hansheng. 1936. Landlord and Peasant in China. New York: International Publisher, p. 37.

Cheng, Lucie, and Suellen Cheng. 1984. Chinese Women of Los Angeles, A Social Historical Survey. In Linking Our Lives: Chinese American Women of Los Angeles. Los Angeles: Asian American Studies Center, University of California, Los Angeles and Chinese Historical Society of Southern California.

Faure, David. 1989. The Rural Economy of Pre-Liberation China: Trade Expansion and Peasant Livelihood in Jiangsu and Guangdong, 1870-1937. Hong Kong: Oxford University Press, p. 215.

Freedman, Maurice. 1958. Lineage Organization in Southeastern China. London: University of London, Athlone Press, p. 17.

65 I refer Yitang and Sam as the immigrant generation and their American-born, -raised, or -educated children as the younger or the second generation though they belong to a three-generation family history. 
Fukutake, Tadashi. 1967. Asian Rural Society: China, India, Japan. Seattle: University of Washington, p. 86.

Grimm, T. 1977. Academies and the Urban System in Kwangtung. In The City in Imperial China. Edited by G. Skinner. Stanford: Stanford University Press.

Hayes, James. 1982. Written Materials in the Village World. In Popular Culture in Late Imperial China. Edited by David Johnson, Andrew J. Nathan and Evelyn S. Rawski. Berkeley: University of California Press, p. 87.

Ho, Ping-ti. 1959. Studies on the Population of China, 1368-1953. Cambridge: Harvard University Press, p. 283.

Ho, Ping-ti. 1962. The Ladder of Success in Imperial China: Aspects of Social Mobility, 1368-1911. New York: Columbia University Press, p. 314.

Ho, Ping-ti. 2000. The Ladder of Success in Imperial China. In A Cultural History of Civil Examinations, in Late Imperial China. Edited by Benjamin A. Elman. Berkeley and Los Angeles: University of California Press.

Hsiao, King-Chuan. 1960. Rural China: Imperial Control in the Nineteenth Century. Seattle: University of Washington Press.

Kulp, Daniel Harrison, II. 1966. Country Life in South China: The Sociology of Familism-Phenix Village, Kwantung, China. Taibei: Cheng-Wen Publishing Co, p. 86f.

Liu, Boji (Pei Chi). 1958. Guangdong Shuyuan Zhiduo [System of Guangdong Academies]. Taibei: Taiwan Books.

Liu, Boji. 1976. Meiguo Huaqiao Shi (A History of the Chinese in the United States of America). Taibei: Commission of Overseas Chinese Affairs, Republic of China, pp. 174-75.

Liu, Haiming. 2005. The Transnational History of a Chinese Family. New Brunswick: Rutgers University Press, pp. 13-14.

Mann, Susan. 2000. The Male Bond in Chinese History and Culture. The American Historical Review 105: 1600-14. [CrossRef]

Marks, Robert B. 1984. Rural Revolution in South China: Peasants and the Making of History in Haifeng Country, 1570-1930. Madison: The University of Wisconsin Press, pp. 54-64.

Mason, William. 1967. The Chinese in Los Angeles. Museum Alliance Quarterly 6: 20-28.

Mazumda, Sucheta. 1998. Sugar and Society in China: Peasants, Technology, and the World Market. Cambridge: Harvard University Press, p. 54.

Mei, Weiqiang, and Guoxiong Zhang, eds. 2001. Wuyi huaqiao huaren shi [A History of Overseas Chinese in the Five Districts]. Guangzhou: Guandong gaodeng jiaoyu chubanshe, p. 29.

Parker, E. H. 1901. John Chinaman and a Few Others. London: John Murray, p. 70.

Qu, Dajun. 1997. Guangdong Xinyu [New Things in Guangdong]. Beijing: Zhonghua shuju, p. 464.

Shiga, Shuzo. 1978. Family Property and the Law of Inheritance in Traditional China. In Chinese Family Law and Social Change. Edited by David Buxbaum. Seattle: University of Washington Press.

Skinner, William. 1964. Marketing and Social Structure in China, Part 1. Journal of Asian Studies 1: 34.

Skinner, G. William. 1971. Chinese Peasants and the Closed Community: An Open and Shut Case. Comparative Studies in Society and History 13: 270-81. [CrossRef]

Takaki, Ronald. 1998. A History of Asian Americans: Strangers from a Different Shore. New York: Little, Brown and Company, p. 33.

Wakeman, Frederic, Jr. 1966. Strangers at the Gate: Social Disorder in South China, 1839-1861. Berkeley: University of California Press, p. 180.

Wakeman, Frederic, Jr. 1975. The Fall of Imperial China. New York: The Free Press, p. 14.

Yang, Wanxiu, and Zhuo'an Zhong. 1996. Guangzhou jianshi [A Concise History of Guangzhou]. Guangzhou: Guangdong renmin chubanshe, pp. 170-72.

Zhang, Zhongli. 1955. The Chinese Gentry; Studies on Their Role in Nineteenth-Century Chinese Society. Seattle: University of Washington Press.

(C) 2019 by the author. Licensee MDPI, Basel, Switzerland. This article is an open access article distributed under the terms and conditions of the Creative Commons Attribution (CC BY) license (http://creativecommons.org/licenses/by/4.0/). 